Mutation Research, 59 (1979) 49-60

(C) Flsevier/North-Holland Biomedical Press

\title{
EFFECTS OF DNA DAMAGING AGENTS ON CULTURED FIBROBLASTS DERIVED FROM PATIENTS WITH COCKAYNE SYNDROME
}

\author{
M.H. WADE * and E.H.Y. CHU \\ Department of Human Genetics, University of Michigan Medical School, Ann Arbor, \\ MI 48109 (U.S.A.) \\ (Received 19 January 1978) \\ (Revision received 15 August 1978) \\ (Accepted 28 August 1978)
}

\section{Summary}

The cytotoxic action of physical and chemical agents on 10 skin fibroblast strains in culture derived from individuals with Cockayne's syndrome was measured in terms of colony-forming ability. As compared to fibroblasts from normal donors, all Cockayne cell strains tested exhibited a significantly increased sensitivity to UV light and a normal sensitivity to X-rays. Cells from two sets of parents of unrelated Cockayne children showed an intermediate level of UV sensitivity. There was no effect of $0.5 \mathrm{mM}$ caffeine on UV survival in normal and two Cockayne strains tested, indicating that postreplicational repair in Cockayne cells as measured by caffeine sensitivity was probably normal.

Sensitivity of normal and Cockayne cells to the chemical carcinogens and mutagens 4NQO, N-AcO-AAF, ICR-170 and EMS was also compared. An increased sensitivity of Cockayne cells to $4 \mathrm{NQO}$ or N-AcO-AAF, but not to ICR-170 or EMS, was observed. However, unlike the intermediate UV sensitivity, the cell strains from two parents of Cockayne patients showed the same sensitivity to N-AcO-AAF or 4NQO as fibroblasts from normal individuals.

Quantitation of damage to the DNA after $20 \mathrm{~J} \cdot \mathrm{m}^{-2} \mathrm{UV}$ irradiation indicates normal levels of $\left[{ }^{3} \mathrm{H}\right]$ thymidine incorporation in the Cockayne cells, in contrast to UV-irradiated xeroderma pigmentosum cells (XP 12BE) in which there was a very low level of repair synthesis. Moreover, we have shown previously that

\footnotetext{
* Present address: Medical Biological Laboratories T.N.O., Lange Kleiweg 139, P.O. Box 45, 2280 AA Rijswijk (Z.H.), The Netherlands.

Abbreviations: N-ACO-AAF. N-acetoxy-2-acetylaminofluorene: EMS, ethyl methanesulfonate: 4NQO, 4-nitroquinoline-1-oxide; ICR-170, 2-methoxy-6-chloro-9-[3-(ethyl-2-chloroethyl)aminopropylaminolacridine dihydrochloride; MEM, minimum essential medium; PBS, phosphatebuffered saline; UV, ultraviolet light; XP, xeroderma pigmentosum; CS, Cockayne syndrome.
} 
excision of UV-induced pyrimidine dimers in 2 of the 10 Cockayne cell strains was normal.

\section{Introduction}

There are three major forms of DNA repair in mammalian cells: excision repair, post-replicational repair and photoreactivation. In human cells, although monomerization of pyrimidine dimers by photoreactivation has been reported to occur under certain cell culture conditions [22,32], the major repair mechanism appears to be excision repair. There may be two modes of excision repair - a long patch and a short patch. The first mode is typified by the excision of ultraviolet light-induced pyrimidine dimers, and the second mode of repair occurs after those kinds of damage that cause breakage of the DNA backbone, such as X-ray-induced lesions. The apparent differences between the two systems are the size of the gap to be filled in and the need for the incision steps of excision repair.

In human cells, UV-induced pyrimidine dimers and lesions induced by certain chemicals, such as $N$-acetoxy-2-acetylaminofluorene ( $\mathrm{N}-\mathrm{AcO}-\mathrm{AAF}$ ), are substrates for excision repair. The $\mathrm{N}$-AcO-AAF damage mimics UV damage in the following ways: (a) both are repaired by a long patch mechanism $(\sim 100$ nucleotides) [25], (b) cells derived from patients with xeroderma pigmentosum (XP) deficient in repairing UV damage are also deficient in the ability of repairing $\mathrm{N}$-AcO-AAF damage $[6,30]$, and (c) XP cells are more sensitive than normal cells to the cytotoxic and mutagenic activity of both UV and N-AcO-AAF [20]. However, studies based on DNA-repair synthesis showed that removal of $\mathrm{N}$-AcO-AAF and UV lesions differed in the initial rate of removal [2]. Ahmed and Setlow [1] further showed that there are different rate-limiting steps in excision repair of UV and N-AcO-AAF damaged DNA in normal human fibroblasts and suggested a model involving a complex of enzymes to explain their data.

We have recently studied the radiation sensitivity of skin fibroblasts derived from a number of patients with a rare hereditary disorder, the Cockayne syndrome, in whom one characteristic clinical feature is skin hypersensitivity to sunlight. The syndrome was first described in two siblings by Cockayne in 1936 and more than 20 other cases have been documented since then [3]. The syndrome is an autosomal recessive disease characterized by cachectic dwarfism, retinal abnormalities, microcephaly, deafness, neural defects and retardation of growth and development after birth [11]. Carcinomas of the skin as a result of the hyperphotosensitivity are not seen in Cockayne patients, although they are quite common in XP patients. Cultured skin fibroblasts from two Cockayne patients have been shown to exhibit marked UV sensitivity as measured by colony-forming ability, but their sensitivity to X-rays was not different from normal fibroblasts $[27,28]$.

The excision of the UV-induced pyrimidine dimers was also found to be normal in the cells derived from the two Cockayne patients [28].

In this paper we present the results of cytotoxicity studies using several agents thought to induce long or short patch repair on a variety of human 
cell strains, including those developed from 8 additional Cockayne patients, parents of two unrelated patients, as well as from several normal and XP individuals. These results not only confirm our earlier findings on marked UV-sensitivity of Cockayne cells but also reveal a differential UV sensitivity in heterozygotes, a lack of caffeine effect on UV inactivation of Cockayne cells, and an increased sensitivity of these cells to agents that elicit long-patch DNA repair.

\section{Materials and methods}

\section{Cell cultures}

All the 10 strains of CS skin fibroblasts used in this study were either originated in our laboratory or supplied by other investigators (Table 1). New nomenclature is being implemented to clarify the strains and their origins; the old designation is in parenthesis. All cells were grown in modified Minimum Essential Medium [9]. Our formulation includes a $50 \%$ increase in concentrations of essential amino acids, a $100 \%$ increase in concentrations of nonessential amino acids, $1 \mathrm{mM}$ Lglutamine, $1 \mathrm{mM}$ sodium pyruvate and inorganic salts according to Earle [10]. The MEM for growing human fibroblasts also contained $15 \%(\mathrm{v} / \mathrm{v})$ undialyzed fetal-calf serum, $100 \mathrm{IU} / \mathrm{ml}$ penicillin $\mathrm{G}$ and $100 \mu \mathrm{l}$ streptomycin. All strains, both from CS and normal donors, were in the third to thirteenth transfer when used for experiments. The plating procedure and conditions for radiation or chemical exposure of cells are described in the figure legends.

\section{DNA-repair synthesis}

The method used for measuring DNA-repair synthesis was essentially that described by Lohman et al. [18] for NaI gradient analysis. Cells were seeded into $60-\mathrm{mm}$ dishes with complete medium and allowed to grow to near confluency. The day before the experiment, the medium was changed to one containing no exogeneous thymidine, uridine or hypoxanthine but $15 \%$ undialyzed fetal-calf serum. $2 \mathrm{~h}$ prior to UV-irradiation $1 \mu \mathrm{M}$ 5-fluorodeoxyuridine (FrdU) was added to stop de novo DNA synthesis, and $0.5 \mathrm{mM} 5$-bromodeoxyuridine (BrdU) was added in the event that NaI gradients were to be run. The medium was removed and cells were either unirradiated or exposed to UV at $20 \mathrm{~J} \cdot \mathrm{m}^{-2}$. Medium containing $1 \mu \mathrm{M}$ FrdU, $0.5 \mathrm{mM} \mathrm{BrdU}, 1 \mathrm{mM}$ hydroxyurea and [ $\left.{ }^{3} \mathrm{H}\right]$ thymidine $(10 \mu \mathrm{Ci} / \mathrm{ml}, 50 \mathrm{Ci} / \mathrm{mmole})$ was added and incubation continued for varying lengths of time. The cells were rinsed with PBS, trypsinized, pelleted and stored at $-20^{\circ} \mathrm{C}$. DNA was precipitated by several washes of $5 \%$ trichloroacetic acid and solubilized by heating to $90^{\circ}$ for $20 \mathrm{~min}$. Diphenylamine assays were performed and the incorporated radioactivity in each sample (CPM/ $/ \mu \mathrm{g}$ DNA) was determined by liquid scintillation counting.

\section{Chemicals}

N-AcO-AAF was a gift from Dr. Justin McCormick, Michigan State University, East Lansing, MI (U.S.A.), ICR-170 from Dr. H.J. Creech, Institute for Cancer Research, Philadelphia, PA (U.S.A.) and 4NQO from Dr. Sohei Kondo, University of Osaka (Japan). EMS was purchased from Eastman Organic 
Chemicals, Rochester, NY (U.S.A.). Components of growth media and fetal calf serum were obtained from Grand Island Biological Co., Grand Island, NY (U.S.A.). All other chemicals used in these studies were obtained from Sigma Chemical Co., St. Louis, MO (U.S.A.).

\section{Results}

We have previously shown [28] that two Cockayne cell strains, CS2AN (UM 102) and CS1AN (UM 106), are equally sensitive to X-rays as skin fibroblasts in culture from normal donors. This is confirmed by survival analysis of $\mathrm{X}$-irradiated Cockayne cells from 6 additional and unrelated patients included in the present study (data not shown).

Fig. 1 shows cell survival, as a function of UV dose, of 9 Cockayne cell strains and 2 normal cell strains. With the exception of strains CS6MO and CS1OWI all strains have been tested at least 3 times. All the Cockayne cell strains are significantly more UV-sensitive than the normal cells, and a difference in UV-sensitivity is seen between cell strain CS9SA and those derived from other CS patients. This has been repeated 3 times with similar results. The UV. sensitivity also appears to be independent of sex and age.

The inheritance of Cockayne syndrome has been considered as autosomal recessive because the disorder occurs in both sexes and the parents of affected individuals are normal and asymptomatic. Fibroblast strains derived from parents of two unrelated Cockayne patients have also been examined to see if heterozygosity could be detected in vitro. As can be seen from Fig. 2, cells of

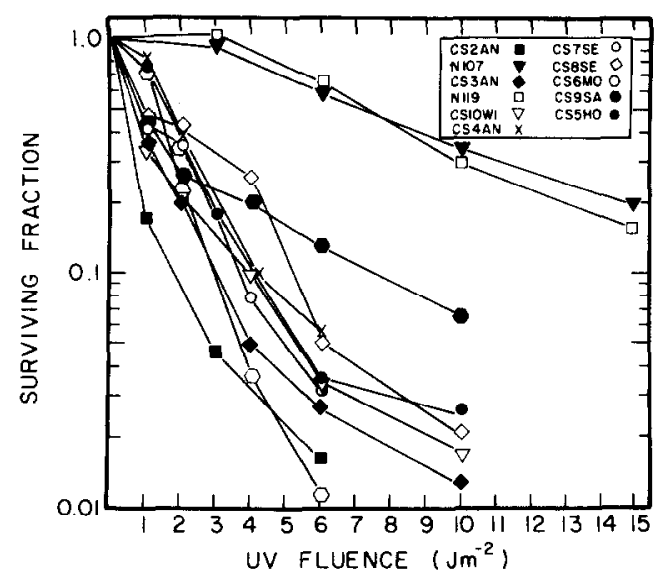

Fig. 1. UV sensitivity as measured by colony-forming ability in diploid skin fibroblast strains derived from 9 unrelated Cockayne patients and 2 normal donors. Cells were plated in 100-mm plastic petri plates (Lux), and allowed to attach. The medium was removed and the cells were irradiated with a 15 -W Champion G1518 germicidal UV lamp, peak at $254 \mathrm{~nm}$. The UV flux was $1 \mathrm{~J} \cdot \mathrm{m}^{-2} \cdot \mathrm{s}^{-1}$ as determined by a Black-Ray UV meter, model J-225. Complete medium with $15 \%$ calf serum and antibiotics was added, the cultures were incubated with medium changes weekly, and colonies were scored $14 \rightarrow 21$ days after UV irradiation. All operations were conducted under strict light control at wavelengths longer than $700 \mathrm{~nm}$. Plating efficiencies of fibroblasts varied between 10-50\%. All points are the result of 5-10 replicate plates. 
all 4 parents show intermediate levels of UV sensitivity as measured by colonyforming ability. These results were reproduced at least 2 times for each strain.

From our data, a regression analysis on the linear portion of the various UVsurvival curves was performed. As seen in Table 2, the $D_{0}$ values fall into 3 major groups that are non-overlapping. The values for normal cells fall between 5.5 and $8.0 \mathrm{~J} \cdot \mathrm{m}^{-2}$, those for cells from parents range from 3.7 and 4.2 and those for Cockayne cells between 0.5 and 2.5. An interesting interpretation of these results would lead us to infer that a co-dominantly expressed gene may be indicated by the intermediate UV-sensitivity in obligatory heterozygotes.

A small group of XP patients, termed 'XP Variants', exhibit the usual clinical symptomes, but their cells have normal levels of excision-repair $[6,26]$. Lehmann et al. [15] showed that fibroblasts from 3 XP Variants were defective in the ability to convert newly synthesized DNA from low to high molecular weight in UV-irradiated cells. It has been shown that caffeine markedly inhibits postreplicational repair in rodent cells [12,14]. Postreplicational repair of normal human cells was rapid and caffeine-resistant, whereas in cells from XP Variants the process of replicational repair was relatively slow and drastically inhibited by caffeine [15]. More recently, Lehmann et al. [16] have extended these observations to a total of 5 excision-proficient XP Variants. In addition, a less severe defect in postreplication repair has been found in excision-defective $\mathrm{XP}$ patients belonging to the Complementation Groups A, B, C and D [16]. Complementation Group $\mathrm{E}$ and all other cell strains studied showed a response that was not significantly different from that of cells from normal donors. Maher et al. [19] have also shown that XP Variants are more sensitive to UV light in the presence of caffeine than in its absence.

We examined the UV-sensitivity of 2 Cockayne cell strains in the presence and absence of $0.5 \mathrm{mM}$ caffeine. The result (Fig. 3) clearly shows that there is no modifying effect of caffeine on UV-sensitivity of either normal or Cockayne strain CS2AN. The lack of caffeine effect was also demonstrated with strains CS5HO and CS9SA. In contrast, there was a significant effect of caffeine on

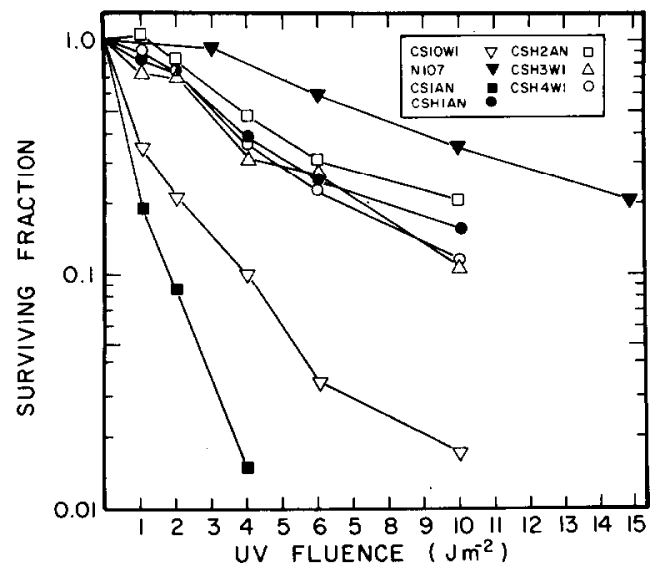

Fig. 2. UV-sensitivity of cells derived from parents of Cockayne children. Cells were treated as in Fig. 1. 
TABLE 1

STRAINS OF CULTURED SKIN FIBROBLASTS USED IN THIS STUDY

\begin{tabular}{|c|c|c|c|}
\hline $\begin{array}{l}\text { Strain } \\
\text { designation }\end{array}$ & $\operatorname{Sex}$ & $\begin{array}{l}\text { Age } \\
\text { (at biopsy) }\end{array}$ & Source and comments \\
\hline \multicolumn{4}{|l|}{ Normal } \\
\hline N119 (UM119) & d & 25 & $\begin{array}{l}\text { R.D. Schmickel, Univ. of Michigan } \\
\text { Medical School }\end{array}$ \\
\hline N107 (UM107) & $\delta$ & 7 & $\begin{array}{l}\text { R.D. Schmickel, Univ. of Michigan } \\
\text { Medical School }\end{array}$ \\
\hline \multicolumn{4}{|l|}{ Parents } \\
\hline CSH1AN (UM114) & q & 33 & $\begin{array}{l}\text { R.D. Schmickel, Univ. of Michigan, } \\
\text { mother of CS1AN }\end{array}$ \\
\hline CSH2AN (UM115) & $\delta$ & 34 & $\begin{array}{l}\text { R.D. Schmickel, Univ, of Michigan, } \\
\text { father of CS1AN }\end{array}$ \\
\hline CSH3WI (UM117) (CSH233CTO) & q & 35 & $\begin{array}{l}\text { A. Hunter, Univ, of Manitoba, Winnipeg, } \\
\text { mother of CS1OWI }\end{array}$ \\
\hline CSH4WI (UM118) (CSH234CTO) & $\delta$ & 32 & $\begin{array}{l}\text { A. Hunter, Univ, of Manitoba, Winnipeg, } \\
\text { father of CS10WI }\end{array}$ \\
\hline \multicolumn{4}{|l|}{ Patients } \\
\hline CS1AN (UM106) & $q$ & 3 & R.D. Schmickel, Univ, of Michigan \\
\hline CS2AN (UM102) & $\phi$ & 4 & R.D. Schmickel, Univ. of Michigan \\
\hline CS3AN (UM110) & 0 & 13 & $\begin{array}{l}\text { R.D. Schmickel, Univ, of Michigan, } \\
\text { brother of CS4AN }\end{array}$ \\
\hline CS4AN (UM111) & 0 & 16 & $\begin{array}{l}\text { R.D. Schmickel, Univ, of Michigan, } \\
\text { brother of Cs3AN }\end{array}$ \\
\hline CS5HO (CS2BE) (CE) & o & 20 & A. Beaudet, Baylor Univ. Sch. of Med. \\
\hline $\operatorname{CS} 6 \mathrm{MO}(\mathrm{KR})$ & 9 & & H. Goldberg, Montreal Children's Hospita \\
\hline CS7SE (CSRDSE) (7447) & Q & $\mathbf{9}$ & J. Hall, Univ. of Washington Sch. of Med. \\
\hline CS8SE (70-22) & $\delta$ & 17 & J. Hall, Univ. of Washington Sch. of Med. \\
\hline $\operatorname{CS9SA}(\operatorname{CSNNSD})(\mathrm{NN})$ & t & 15 & K.L. Jones, Univ. of California, San Diego \\
\hline CS1OWI (CS235CTO) (5849) & o & 4 & A. Hunter, Univ. of Manitoba, Winnipeg \\
\hline XP12BE & \& & 7 & $\begin{array}{l}\text { Amer. Type Culture Collection, } \\
\text { Xeroderma pigmentosum group A }\end{array}$ \\
\hline XPABE & $\delta$ & 27 & $\begin{array}{l}\text { Amer. Type Culture Collection, } \\
\text { Xeroderma pigmentosum Variant }\end{array}$ \\
\hline
\end{tabular}

survival when cells from an XP Variant (XP4BE) were UV-irradiated. Thus, at least in the 3 Cockayne cell strains studied survival as measured by caffeine sensitivity appears normal after UV-irradiation.

The degrees of DNA-repair synthesis following UV-irradiation of a Cockayne cell strain (CS2AN), an XP (A) strain (XP12BE) and a normal strain (N119) were compared. As seen in Table 3 , considerable amounts of $\left[{ }^{3} \mathrm{H}\right]$ thymidine incorporation were observed in normal and Cockayne cells after exposure to $\mathrm{UV}$ at $20 \mathrm{~J} \cdot \mathrm{m}^{-2}$. As expected, this increase in $\left[{ }^{3} \mathrm{H}\right]$ thymidine incorporation was not seen in UV-irradiated XP cells. Similar results were obtained with another CS strain, CS5HO.

It has been shown that XP cells are sensitive to agents, such as UV light, that are considered to induced long-patch repair $[25,31,33]$. These agents 
TABLE 2

$D_{0}$ VALUES CALCULATED FROM UV-SURVIVAL CURVES OF VARIOUS NORMAL AND CS FIBROBLAST STRAINS

\begin{tabular}{lll}
\hline Donor & Cell strain & $\begin{array}{l}D_{0} \\
\left(\mathrm{Jm}^{-2}\right)\end{array}$ \\
\hline Normal individuals & N107 & 7.0 \\
& N107 & 8.9 \\
& N107 (caffeine) & 5.5 \\
Parents of Cockayne patients & CSH1AN & 8.0 \\
& CSH2AN & 4.2 \\
& CSH3WI & 4.2 \\
Patients with Cockayne syndrome & CSH4WI & 3.7 \\
& CS5HO & 3.9 \\
& CS9SA & 1.8 \\
& CS2AN & 1.5 \\
& CS8SE & 0.5 \\
& CS7SE & 2.5 \\
& CS6MO & 1.8 \\
& CS3AN & 1.6 \\
& CS4AN & 1.0 \\
& & 2.0 \\
\hline
\end{tabular}

include N-AcO-AAF, ICR-170 and 4-nitroquinoline-1-oxide (4NQO). Shortpatch repair is characteristically seen in cells after exposure to X-rays, ethyl methanesulfonate (EMS) or 4NQO [25]. The following summarizes the results of cell-survival studies of different strains of human fibroblasts after treatment with various test compounds. All compounds were tested in strain CS2AN at least 2 times and often several other CS strains were also examined.

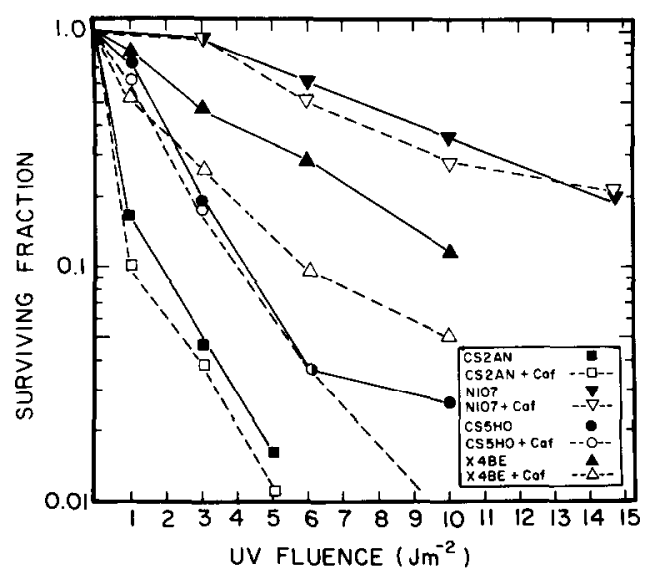

Fig. 3. UV-sensitivity of normal and Cockayne fibroblasts in the presence or absence of $0.5 \mathrm{mM}$ caffeine. Cells were treated under conditions as in Fig. 1 except that medium containing $0.5 \mathrm{mM}$ caffeine was added to half the plates after $U V$-irradiation for the duration of the experiment. The curve extending past the data points is reflective of an additional point at less than $1 \%$ survival. 
TABLE 3

AMOUNT OF [ ${ }^{3}$ H]-THYMIDINE INCORPORATION IN UV-IRRADIATED AND NON-IRRADIATED HUMAN FIBROBLAST STRAINS DURING VARIOUS POSTIRRADIATION PERIODS

\begin{tabular}{|c|c|c|c|c|}
\hline \multirow[t]{2}{*}{ Cell strain } & \multirow[t]{2}{*}{ Donor phenotype } & \multicolumn{3}{|c|}{ Radioactivity (UV/no UV) ${ }^{a}$} \\
\hline & & $0.5 \mathrm{~h}$ & $2 \mathrm{~h}$ & $3.5 \mathrm{~h}$ \\
\hline N119 & Normal & $\frac{125}{18}(6.94)$ & $\frac{310}{25}(12.40)$ & $\frac{560}{56}(10.00)$ \\
\hline CS2AN & Cockayne syndrome & $\frac{131}{24}(5.46)$ & $\frac{350}{32}(10.93)$ & $\frac{600}{58}(10.34)$ \\
\hline XP12BE & Xeroderma pigmentosum & $\frac{70}{72} \quad(0.97)$ & $\frac{95}{110}(0.86)$ & $\frac{155}{180}(0.86)$ \\
\hline
\end{tabular}

a The ratios of total incorporated radioactivity in counts per minute per $\mu \mathrm{g}$ DNA between UV-irradiated $\left(20 \mathrm{~J} \cdot \mathrm{m}^{-2}\right)$ and unirradiated cell populations.

Fig. 4A shows that the colony-forming ability of Cockayne and XP cell strains exposed to N-AcO-AAF differs from that of normal cells. Similar results were seen with 2 other CS strains, CS5HO and CS7SE. Since N-AcO-AAF reacts directly with DNA [21], our finding strengthens the supposition that the UV-sensitivity exhibited by these cells is the result of damage to the DNA rather than some other changes such as alterations of the cell membrane. It also suggests that it is probably the excision-repair that is defective in fibroblasts from Cockayne patients. Fig. 4B shows that the colony-forming ability of Cockayne and XP cells exposed to $4 \mathrm{NQO}$ differs significantly from that of normal cells. This result was also confirmed in strain CS7SE. 4NQO is an agent that is supposed to induced both long- and short-patch repair. Our results confirm a long-patch-repair effect of this compound as measured by colony-forming ability in XP and Cockayne cells. $\Lambda$ surprising observation was made when heterozygous cell strains, CSH2AN and CSH3WI, derived from the parents of Cockayne patients were exposed to N-AcO-AAF. Unlike their response to UV, the strains showed the same sensitivity to these two chemicals as fibroblasts from normal donors. This experiment was performed twice -xith the 2 heterozygote strains for their response to N-AcO-AAF and one time for $4 \mathrm{NQO}$.

EMS has a similar cytotoxic effect on normal, XP and Cockayne cells (Fig. 4C). CS2AN was also examined with similar results. This finding, together with normal results with X-rays (Schmickel et al. [28] and this study), support the theory that strand breaks or small lesions induced by EMS or X-irradiation in the DNA are repaired as efficiently in Cockayne cells as in normal cells.

Finally, ICR-170H has a similar effect on normal (N119), XP (XP12BE) and Cockayne (CS2AN) cells (Fig. 4D). This experiment was performed 3 times with strain CS2AN. Although ICR-107G has been shown by Regan and Setlow [25] to cause bromouracil photolysis in XP cells and has been termed a longpatch-repair inducer, these results are not confirmed by our survival curves. However, the two techniques are measuring different aspects of the response to ICR-170 over different time periods. It was also noted by these investigators that the ICR-170G results were near the resolution limits of their experiment. 

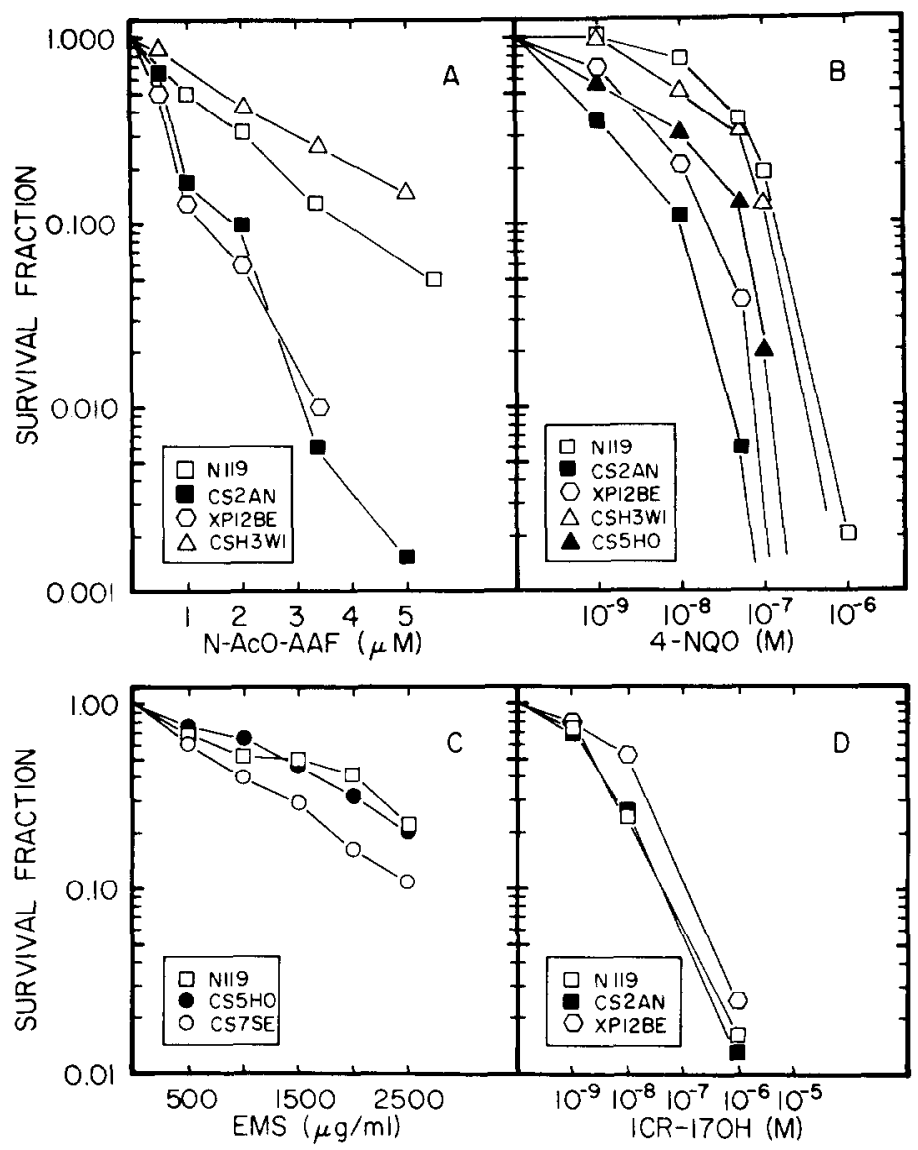

Fig. 4. (A). Effect of N-ACO-AAF on cell survival. Cells were plated and allowed to attach overnight in complete MEM. The medium was removed, and serum-free medium was added to each plate. The test compound was added to each plate in $100 \%$ anhydrous ethanol and mixed immediately. After $3 \mathrm{~h}$, the medium was removed with no rinsing and complete medium containing serum was added to each plate followed by weekly medium changes. Colonies were scored after 14-21 days. (B). Effect of 4 NQO on cell survival. Cells were treated as in (A) with 2 exceptions. The chemical was left on the plates for 90 min and, after its removal, the plates were rinsed 1 time with PBS. The curves extending past the data points are indicative of data points represting less than $0.1 \%$ survival. (C). Effect on EMS on colony-forming ability. Cells were treated as in (A) except that the compound was initially mixed with PBS rather than $100 \%$ ethanol and appropriate dilutions were added to cell cultures for $2 \mathrm{~h}$. (D). Effect of ICR-170H on cell survival. The stock solution of ICR-170H was made in $0.01 \mathrm{~N} \mathrm{HCl}$ and further dilutions were made in PBS. Cells were plated and allowed to attach overnight. The medium was replaced with serum-frec medium, and the test compound was added for $1 \mathrm{~h}$ at $37^{\circ} \mathrm{C}$. The plates were washed once with PBS and complete medium was added. Medium changes were made weekly and colonies were fixed, stained and counted after $14-21$ days.

\section{Discussion}

Individuals with CS are sun-sensitive, and this UV-sensitivity has also been demonstrated in vitro by colony forming-ability experiments (Schmickel et al. [28] and this study). This observation is similar to that seen in xeroderma pigmentosum. However, the two syndromes do not share other clinical features 
including tumor indices. The cellular responses to UV are also dissimilar, thus suggesting that different molecular defects may be involved. For instance, the ability to excise UV-induced pyrimidine dimers appears normal in Cockayne cells [28], in sharp contrast to most XP cells excepting XP Variants. Another difference between Cockayne and XP cells is the extent of DNA-repair synthesis after UV-irradiation. Using the method of Luhman et al. [18] our DNA quantitation studies show that UV-irradiated Cockayne cell strain (CS2AN) underwent unscheduled DNA synthesis to the same extent as irradiated normal cells. On the other hand, XP cells of different Complementation Groups exhibit variable but subnormal levels of repair synthesis [7]. Using the method of Kleijer et al. [13], our autoradiography data (unpublished) on two Cockayne strains (CS2AN and CS1AN) and one normal strain are also consistent with the DNA-quantitation data (Table 3).

In the present study, 4 chemical mutagens known to act on DNA were selected to test their cytotoxicity against both Cockayne cells and the cells derived from obligatory heterozygotes. The fact that Cockayne cells, as compared to normal cells, exhibit a marked increase in sensitivity to UV, N-AcO$\mathrm{AAF}$ and $4 \mathrm{NQO}$ suggests that the loss of proliferative capacity of the treated Cockayne cells is due to their reduced ability to repair the damage in DNA caused by these agents. It can be further inferred that it is probably one of the many steps of the excision-repair process, and not the caffeine-sensitive postreplicational repair, that is defective in the fibroblasts from Cockayne patients.

It is evident that Cockayne cells, as compared to normal cells, are more sensitive to most of the agents which are supposed to induce long-patch repair (N-AcO-AFF, UV, 4NQO). On the other hand, Cockayne cells and normal cells are equally sensitive to the cytotoxic action of those agents which presumably leads to repair of shorter stretches of the DNA strands (EMS, X-ray and possibly, ICR-170H). The presumed difference between these two forms of repair is the amount of gap-filling required and the need for incision enzymes in long-patch repair.

One of the most interesting observations of the present study is the demonstration of an intermediate sensitivity, specifically to UV and not to the two 'UV-mimetic' chemical mutagens (N-AcO-AAF and 4NQO), as expressed by skin fibroblasts derived from parents of Cockayne patients. This result suggests that UV response may be a more sensitive indication for repair of DNA damage in human cells, however there is a greater difference between normal and CS cells in response to UV than to the mutagens.

The intermediate UV-sensitivity in heterozygous cells suggests the presence of a co-dominantly expressed gene. Further studies may show this factor to be helpful for heterozygote detection at the cellular level in prenatal diagnosis. In contrast, cells from XP heterozygotes are not different from normal cells in their response to UV irradiation [7], thus indicating typical inheritance.

The primary molecular defect responsible for UV-sensitivity in Cockayne syndrome is not clear, but there are several possibilities. A decrease in fidelity of DNA polymerase has been implicated in senescing human fibroblasts [17] and leukemic lymphocytes in culture [29], but we are unaware of any report on fidelity studies of a DNA-repair polymerase specific for long-patch repair. A study in our laboratory indicates that the rates of spontaneous and UV-induced 
gene mutations in Cockayne fibroblasts were not different from those in fibroblasts from normal donors [24]. If the fidelity of the DNA polymerase were faulty, one would expect a higher mutation rate than normal. We reported [5] that the polymerase levels in Cockayne fibroblasts were sub-normal. However, when the crude extracts were passed through Sephadex G-50 to remove contaminating nucleotides, the average specific activities of total polymerase and $B$ polymerase were very similar between normal and Cockayne cells. Moses and Beaudet [23] have also confirmed normal polymerase activities in CS cells.

DNA repair as measured by autoradiography or DNA quantitation indicates that gaps in the DNA strands were filled in, but the present experiments give no information concerning strand rejoining by ligase nor the fidelity of the repaired DNA.

\section{Acknowledgemerits}

We are sincerely grateful to the individuals who donated their skin cells for our laboratory investigations, to the physicians who took care of the Cockayne patients for sending us either the biopsy materials or the fibroblast strains initiated in culture, and to the investigators who generously gave us the test compounds used in the present study. We thank Barbara Lamb for performing the X-ray experiments and C.C. Chang, R.D. Schmickel, J.E. Trosko and Carolyn Whitfield for discussions and review of the manuscript. We also thank Deborah Hall who typed the several versions of the manuscript with care, patience and cheerfulness. The research was supported by grants CA 13048 and GM 20608 from the U.S. Public Health Service.

\section{References}

1 Ahmed, F.E., and R.B. Setlow, Different rate-limiting steps in excision repair of ultraviolet and $\mathrm{N}$-acetoxy-2-acetylaminofluorene damaged DNA in normal human fibroblasts, Proc. Natl. Acad. Sci. (U.S.A.), 74 (1977) 1548-1552.

2 Amacher, D.E., J.A. Elliott and M.W. Lieberman, Differences in removal of acetylaminofluorene and pyrimidine dimers from DNA of cultured mammalian cells, Proc. Natl. Acad. Sci. (U.S.A.), 74 (1977) 1553-1557.

3 Bergsma, D., Cockayne syndrome, in: Birth Defects: Atlas and Compendium, Williams and Wilkins, Baltimore, 1973, p. 274.

4 Cerutti, P.A., Repairable damage in DNA: Overview, in: P.C. Hanawalt and R.B. Setlow (Eds.). Molecular Mechanisms for Repair of DNA, Plenum Press, New York, 1975, pp. 3-12.

5 Chu, E.H.Y., R.D. Schmickel, M.H. Wade, C.C. Chang and J.E. Trosko, Ultraviolet light intensity and defect in DNA repair in fibroblasts derived from two patients with Cockayne syndrome, Am. J. Hum. Genet., 27 (1975) $26 a$.

6 Cleaver, J.E., DNA repair with purines and pyrimidines in radiation and carcinogen damaged normal and xeroderma pigmentosum human fibroblasts, Cancer Res., 33 (1973) 362-369.

7 Cleaver, J.E., and D. Bootsma, Xeroderma pigmentosum: Biochemical and genetic characteristics, Annu. Rev. Genet., 9 (1975) $19-38$.

8 Cockayne, E.A., Dwarfism with retinal atrophy and deafness, Arch. Dis. Childhood, 11 (1936) 1-8.

9 Eagle, H., Amino acid metabolism in mammalian cell cultures, Science, 130 (1959) $432-437$.

10 Earle, W.R., Production of malignancy in vitro, IV. The mouse fibroblast cultures and changes seen in the living cells, J. Natl. Cancer Inst., 4 (1943) 165-212.

11 Fujimoto, W.F., M.L. Greene and J.E. Seegmiller, Cockayne's syndrome: Report of a case with hyperlipoproteinemia, hyperinsulinemia, renal disease and normal growth hormone, J. Pediat., 75 (1969) $881-884$.

12 Fujiwara, Y., M. Tatsumi, Replicative bypass repair of ultraviolet damage to DNA of mammalian cells: caffeine sensitive and caffeine resistant mechanisms, Mutation Res., 37 (1976) 91-110. 
13 Kleijer, W.I., E.A. de Weerd-Kastelein, M.L. Sluyter, W. Keijzer, J. de Wit and D. Bootsma, UVinduced DNA repair synthesis in cells of patients with different forms of xeroderma pigmentosum and of heterozygotes, Mutation Res., 20 (1973) $417-428$.

14 Lehmann, A.R., Postreplication repair of DNA in ultraviolet-irradiated mammalian cells, J. Mol. Biol., 66 (1972) 319-337.

15 Lehmann, A.R., S. Kirk-Bell, C.F. Arlett, M.C. Paterson, P.H.M. Lohman, E. de Weerd-Kastelein and D. Bootsma, Xeroderma pigmentosum cells with normal levles of excision repair have a defect in DNA synthesis after UV-irradiation, Proc. Natl. Acad. Sci. (U.S.A.), 72 (1975) 219-223.

16 Lehmann, A.R., S. Kirk-Bell, C.F. Arlett, S.A. Harcourt, E.A. de Weerd-Kastelein, W. Keijzer and P. Hall-Smith, Repair of UV damage in a variety of human fibroblast cell strains, Cancer Res., 37 (1977) 904-910.

17 Linn, S., M. Kairis and R. Holliday, Decreased fidelity of DNA-polymerase activity isolated from ageing human fibroblasts, Proc. Natl. Acad. Sci. (U.S.A.), 73 (1976) 2818-2822.

18 Lohman, P.H.M., M.C. Sluyter and E.A.A. Matthifs, Repair replication in human cells studied by Na I isopycnic centrifugation of DNA in a fixed angle rotor, Anal. Biochem., 54 (1973) $178-187$.

19 Maher, V.M., L.M. Ouelette, M. Mittlestat and J.J. McCormick, Synergistic effect of caffeine on the cytotoxicity of UV irradiated and of hydrocarbon epoxides in strains of Xeroderma pigmentosum, Nature (London), 258 (1975) 760-763.

20 Maher, V.M., and J.J. McCormick, Effect of DNA repair on the cytoxicity and mutagenicity of UV irradiation and of chemical carcinogens in normal and xeroderma pigmentosum cells, in: J.M. Yuhas, R.W. Tennant and J.D. Regan (Eds.), Biology of Radiation Carcinogenesis, Raven Press, New York, 1976 , pp. 129-145.

21 Miller, E.C., U. Jahl and J.A. Miller, Nucleic acid guanine: Reaction with the carcinogen $N$-acetoxy-2acetylaminofluorene, Science, 153 (1966) 1125-1127.

22 Mortelmans, K., J.E. Cleaver, E.C. Friedberg, M.C. Paterson, B.P. Smith and G.H. Thomas, Photoreactivation of thymidine dimers in UV-irradiated human cells: unique dependence on culture conditions, Mutation Res., 44 (1977) $433-446$.

23 Moses, R.E., and A.L. Beaudet, Apurinic DNA endonuclease activities in repair-deficient human cell lines, Nucleic Acids. Res., 5 (1978) 463-473.

24 Powell, S.S., B.J. Lamb and E.H.Y. Chu, personal communication.

25 Regan, J.D., and R.B. Setlow, Two forms of repair in the DNA of human cells damaged by chemical carcinogens and mutagens, Cancer Res., 34 (1974) $3318-3325$.

26 Robbins, J.H., K.H. Kraemer, M.A. Lutzner, B.W. Festoff and H.G. Coon, Xeroderma pigmentosum an inherited disease with sun sensitivity, multiple cutaneous neoplasms, and abnormal DNA repair, Ann. Int. Med., 80 (1974) $221-248$.

27 Schmickel, R.E., E.H.Y. Chu and J.E. Trosko, The definition of a cellular defect in two patients with cockayne syndrome, Pediat. Res., 9 (1975) 317.

28 Schmickel, R.E., E.H.Y. Chu, J.E. Trosko and C.C. Chang, Cockayne's syndrome: a cellular sensitivity to ultraviolet light, Pediatrics, 60 (1977) 135-319.

29 Springgate, C.F', and L.A. Loeb, Mutagenic UNA polymerase in human leukemic cells, Proc. Natl. Acad. Sci. (U.S.A.), 70 (1973) 245-249.

30 Stich, H.F., R.H.C. San, J.A. Miller and E.C. Miller, Various levels of DNA repair synthesis in xeroderma pigmentosum cells exposed to the carcinogens $N$-hydroxy- and $N$-acetoxy-2-acetylaminofluorene, Nature (London), New Biol., 238 (1972) 9-10.

31 Stich, H.R., R.H.C. San and Y. Kawazoe, Increased sensitivity by xeroderma pigmentosum cells to some clinical carcinogens and mutagens, Mutation Res., 17 (1973) $127-137$.

a2 Sutherland, B.M., M. Rice and E.K. Wagner, Xeroderma pigmentosum cells contain low levels of photoreactivating enzyme, Proc. Natl. Acad. Sci. (U.S.A.), 72 (1975) 103-107.

33 Takebe, H., J. Furugama, Y. Miki and S. Kondo, High sensitivity of xeroderma pigmentosum cells to the carcinogen 4 NQO, Mutation Res., 15 (1972) 98-1.00. 